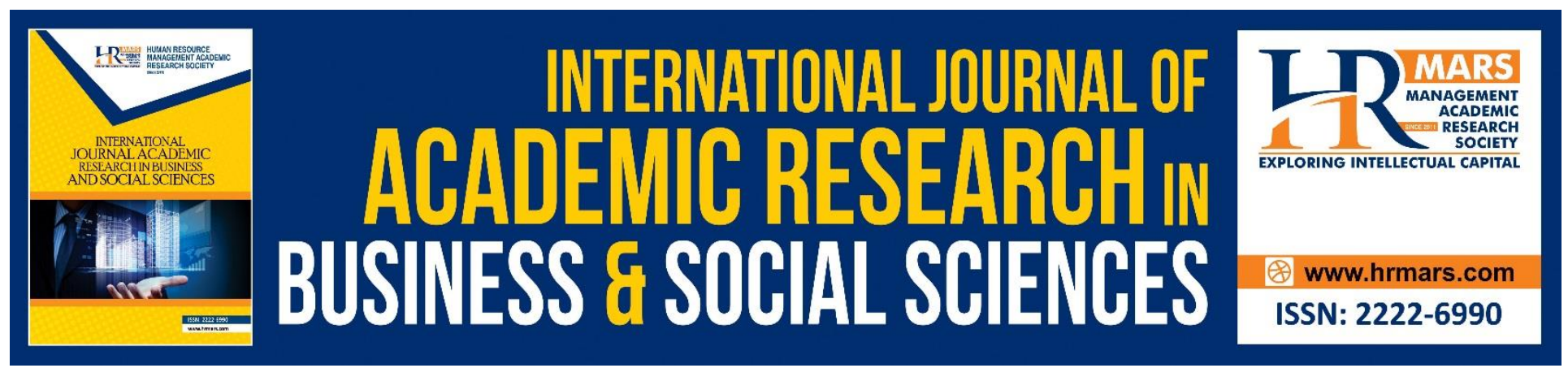

\title{
The Impact of Strategic Management Accounting Adoption on Organizational Effectiveness in Malaysian Manufacturing Companies
}

\author{
Hezlina binti Mohd Hashim, Abdul Mutalib bin Embong and Md Akhir bin M \\ Sharif
}

To Link this Article: http://dx.doi.org/10.6007/IJARBSS/v8-i11/5359

DOI: $10.6007 /$ IJARBSS/v8-i11/5359

Received: 06 Nov 2018, Revised: 27 Nov 2018, Accepted: 06 Dec 2018

Published Online: 10 Dec 2018

In-Text Citation: (Hashim, Embong, \& Sharif, 2018)

To Cite this Article: Hashim, H. binti M., Embong, A. M. bin, \& Sharif, M. A. bin M. (2018). The Impact of Strategic Management Accounting Adoption on Organizational Effectiveness in Malaysian Manufacturing Companies.

International Journal of Academic Research in Business and Social Sciences, 8(11), 1839-1847.

Copyright: (c) 2018 The Author(s)

Published by Human Resource Management Academic Research Society (www.hrmars.com)

This article is published under the Creative Commons Attribution (CC BY 4.0) license. Anyone may reproduce, distribute, translate and create derivative works of this article (for both commercial and non-commercial purposes), subject to full attribution to the original publication and authors. The full terms of this license may be seen

at: http://creativecommons.org/licences/by/4.0/legalcode

Vol. 8, No. 11, 2018, Pg. 1839 - 1847

http://hrmars.com/index.php/pages/detail/IJARBSS

JOURNAL HOMEPAGE

Full Terms \& Conditions of access and use can be found at http://hrmars.com/index.php/pages/detail/publication-ethics 


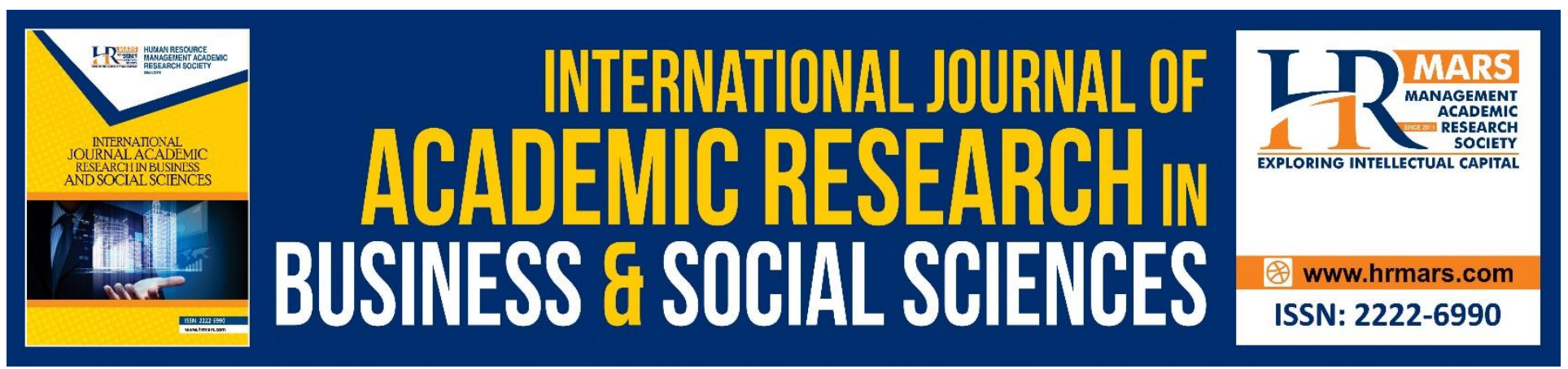

\title{
The Impact of Strategic Management Accounting Adoption on Organizational Effectiveness in Malaysian Manufacturing Companies
}

\section{Hezlina binti Mohd Hashim, Abdul Mutalib bin Embong and Md Akhir bin M Sharif}

Department of Management and Humanities, Universiti Teknologi PETRONAS, Bandar Seri Iskandar, 32610 Seri Iskandar, Perak, Malaysia.

\begin{abstract}
Strategic Management Accounting (SMA) technique plays a vital role in accounting management of an organization. This is because; SMA helps the accountants and other workers to manage their accounting systems efficiently and more orderly arranged. The aim of this study is to find out about technique of SMA that been applied in the organization specifically focused on manufacturing companies and the impact of the technique on organizational effectiveness. The result showed that all the 376 companies applied at least one SMA technique and specifically refers to the industry classification; the highest companies that applied SMA were electrical companies. The result also showed that SMA has impact on organizational effectiveness.
\end{abstract}

Keywords: SMA, SMA Technique, Organizational Effectiveness, Manufacturing Companies, Malaysia

Introduction

SMA is one of techniques in accounting field that being used to simplify human works as compared to traditional method used before, where the SMA is more orderly arrange, more applicable and flexible to be used. To ensure that an organization able to be organized well and had good progress, a proper and well design strategy need to be carried out. Here is where the SMA plays the important role. Studies on SMA have been done since more than 30 years ago either on definition, perception, techniques, influence of applying SMA and numerous others. Different scholars will have different answers for their studies on SMA, which result in varies answers that leads to paradox.

Bromwich (1990) explained SMA as something that allow the management of an organization to be able to see from the bird eye view of the competitors' business technique and procedures which enables the organization to take decision accordingly. How effective an organization are actually being outline by the capability of an organization to survive, endure and make advancement (Edwinah 
\& Augustine, 2013). Hence, for an organization to be effective SMA need to be carried out in the company.

While the organizational effectiveness varies among the organization, the main reason is because an organization will have different culture, environment and workers which explained why an organizational effectiveness can't simply be generalized with other organization. Every organization will have own targets to gain excellent progress constantly due to the situation in this current era where it is highly competitive regardless of the organization size. Therefore, in order to achieve highest success, organizational effectiveness and high performance of the organizations, organizations will design different strategies and techniques (Manzoor, 2012). One of the most important and known practices to achieve organization effectiveness is strategic management accounting. Moreover, the relationship between SMA and organizational effectiveness will be enhanced by including contextual variable.

From the review of past research, many study has been done in advance countries (United Kingdom, United States, Japan, Australia and New Zealand), only a few conducted in developing countries (Thailand, Indonesia and Malaysia). There may be a different element and effect of SMA adoption in Malaysia compared to other advanced countries. Therefore, the objectives of this study are as follows:

(i) To determine the popular SMA practices applied in the manufacturing companies.

(ii) To examine the level of organizational effectiveness as a result of SMA

\section{LITERATURE REVIEW}

\section{STRATEGIC MANAGEMENT ACCOUNTING PRACTICE (SMA)}

SMA had been discussed in the literature thirty years ago and since then a rising number of SMA research have been published (Roslender \& Hart, 2010). According to Tillman and Goddard (2005) as cited in Manzoor, SMA can be referred to the use of financial and non-financial accounting information to support strategic decision making (Manzoor, 2012). Besides that, Simmonds, the father of SMA has clarified that SMA is the provision and analysis of management accounting data about a business and its competitors, for use in developing and monitoring business (Simmonds, 1986). As cited from Roslender and Hart (2003) by Roslender and Hart, SMA can best be defined as 'a specific set of managerial accounting approaches, those which attempt to integrate insights from management accounting and marketing management within a strategic management framework (Roslender \& Hart, 2010). Therefore, SMA is a practices used to strategically manage data related to financial and non-financial accounting in an organization systematically.

Besides that, Langfield-Smith also agreed that there is a different process or different stage in SMA studied by previous researchers (Langfield-Smith, 2008). For example, Dixon and Smith explain that there are four stages of SMA such as: strategic business identification, strategic cost analysis, strategic market analysis and strategy evaluation (Dixon \& Smith, 1993). Furthermore, Lord (1996) also presented that there are six-stage process in SMA which are; (i) Collection of competitor 
information, (ii) Exploitation of cost reduction opportunities, (iii) Matching of accounting emphasis with strategic position, (iv) Collection of competitor information, (v) Exploitation of cost reduction opportunities, and (vi) Matching of accounting emphasis with strategic position (Lord, 1996). Next, under SMA umbrella, it also includes different techniques such as; target costing, life-cycle costing, strategic cost analysis, competitor cost analysis, activity-based costing, activity-based management (sometimes called activity-based cost management), attribute costing, life cycle costing and strategic performance measurement systems. SMA adoption by the industries especially modern manufacturing has improved over the years (Uyar,2010). However, there is a gap between management accounting theory in literature (published paper, journals, books) and management accounting practice in industries (Langfield-Smith, 2008).

However, SMA is a unique technique that is important in strategic decision making and management accounting thus increases company effectiveness. The company is seen as an atomistic unit that is free to choose the best alternative without considering interdependencies with close customers and suppliers. This view of strategy in the mainstream SMA literature has implications for what SMA may consist of, who is implicated in SMA practices and when SMA is performed. There are reviews from literature which recommend that two perspectives on SMA can be used. The first review described SMA which includes a set of strategically oriented accounting techniques. The second review explained that, SMA involved the participations of accounts in corporate strategic decisionmaking procedures (Simon \& Chris, 2008).

In this study, the researcher adopted those techniques such as budgetary control, absorption control, cost volume profit analysis, marginal costing, standard costing, target costing, activity based costing $(A B C)$, activity based management, value chain analysis, benchmarking, product profitability analysis, customer profitability analysis and shareholder value analysis. The researcher will determine which one of the techniques the company in manufacturing industry in Malaysia is adopting.

\section{ORGANIZATIONAL EFFECTIVENESS}

In order to be successful, the organizations must be organized effectively and clearly focus more on organizational effectiveness. So, what is organizational effectiveness? According to Manzoor, organizational is a group of people which formulate independent business identify for some specific purpose and effectiveness can be referred to getting desired outcome within defined resources (Manzoor, 2012). Tran and Tian defined organization as the formation of group of people with the same purpose in achieving something that one person cannot achieve individually (Tran \& Tian, 2013) while Muhammad et al as cited from Manzoor explained that organizational effectiveness is the belief of how efficient the organization effort in order to accomplish the objectives that the organizations target to achieve (Manzoor, 2012). Moreover, organizational effectiveness is also the use of resources without depleting it and without giving unnecessary stress to its members to fulfill the organization's mission and vision (Khan, Khan, Ahmed \& Ali, 2012). It is also supported by Vinitwatanakhun who stated that organizational effectiveness is a significant indicator to show the direction, position and future of the organization (Vinitwatanakhun, 1998). Moreover, she also agreed that measuring the effectiveness of the organization is a continuing activity and widespread. 
Therefore, for this study, organizational effectiveness can be defined as the alignment of structure, process and behavior, best judged in terms of productivity, efficiency and satisfaction, intermediate adaptability, development and long-run survival.

Based on previous literature, the most important in an organization is human resources (employees itself). It is supported by Indira and Joshi; "Organization can be effective when the existing Human Resources are utilized optimally, the potentialities are developed and behavior is channeled towards the expected targets. Organizational effectiveness is the extent to which an organization achieves its goal with the given resources and means" (Indira \& Joshi, 2014). Thus, for an organization to success specifically on SMA, all personnel need to work together as a team and perform task given appropriately. An organization will be able to control the strategic management system and discover safety and support, if the organizational effectiveness concentrate on human resources and association plus assist the workers to attain great technique such as SMA (Vinitwatanakhun, 1998). However, based on previous studies, here is still no suitable organizational effectiveness model that can fit all (Ashraf \& Abd Kadir, 2012). This is because every organization has its own unique identity and dissimilarities, so the result cannot be generalized to other company.

\section{METHODOLOGY}

This study aims to determine which SMA technique adopted by the companies and to examine the level of organizational effectiveness as a result in SMA in manufacturing companies in Malaysia. To get the information needed, survey questionnaire was employed. The questionnaire was sent to 400 respondents from 80 different manufacturing companies all over Malaysia. Out of 400, a total of 375 responses were received that consist of $93.7 \%$ response rate.

The questionnaire were divided into four section which are Section A, B, C and D. Section A contained the questions on organizational background that include the type of industry, annual sales turnover and number of employees in the companies; Section B enclosed about the types of management accounting adopted by the companies using Likert scale ranging from " 1 "= Never, " 2 " $=$ Rarely, " 3 " = Occasionally, " 4 "=Frequently, " 5 "=Very Frequently. Section C include the questions about the benefit/effectiveness of the SMA applied by the companies using Likert scale ranging from " 1 "=Strongly Disagree, "2"=Disagree, "3"=Slightly Agree, "4"=Agree, "5"=Strongly Agree. Section D asked about the impact of contextual variable on organizational effectiveness using Likert scale ranging from "1"=No Impact, " 2 "=Very Slight Impact, " 3 "=Low Impact, "4"=Moderate Impact and " 5 " = Significant Impact.

\section{RESULT AND DISCUSSION}

The first objective of this paper is to determine the popular SMA practices applied in the manufacturing companies of Malaysia. Table 1 demonstrates on the types of strategic management accounting that are presently applied by the companies in Malaysia. Based on the results in Table 1, clearly indicates that all companies implemented at least one out of thirteen strategic management accounting practices stated in the questionnaire. Most of the result for the SMA technique for means above midpoint varies from 3.4 to 4.07. This result shows that manufacturing companies in Malaysia 
INTERNATIONAL JOURNAL OF ACADEMIC RESEARCH IN BUSINESS AND SOCIAL SCIENCES

Vol. 8, No. 11, Nov, 2018, E-ISSN: 2222-6990 @ 2018 HRMARS

has started to appreciate and adopted SMA technique as their accounting management for their companies' strategic purposes. This is supported by study done by Noordin, Zainuddin, \& Tayles and Noordin, Zainuddin, Fuad, \& Mail, based on Malaysia evidence, they stated that Malaysia Electrical and Electronic companies have started to realize the importance of SMA and applied the technique in their management to manage their market competition and strategy implementation (Noordin, Zainuddin, Fuad, \& Mail, 2014 and Noordin, Zainuddin \& Tayles, 2009).

Table 1: Types of SMA Techniques Applied

\begin{tabular}{|l|l|}
\hline$\backslash$ & Mean \\
\hline Budgetary Control & 4.0718 \\
\hline Product Profitability Analysis & 3.9624 \\
\hline Standard Costing & 3.8847 \\
\hline Cost Volume Profit Analysis & 3.8118 \\
\hline Target Costing Profitability & 3.7032 \\
\hline $\begin{array}{l}\text { Customer } \\
\text { Analysis }\end{array}$ & 3.7378 \\
\hline Marginal Costing & 3.6532 \\
\hline Benchmarking & 3.6141 \\
\hline Activity Based Costing & 3.6113 \\
\hline Absorption Costing & 3.5606 \\
\hline Activity Based Management & 3.5296 \\
\hline Shareholder Value Analysis & 3.4332 \\
\hline Value Chain Analysis & 3.4321 \\
\hline
\end{tabular}

Referring to Table 1, the highest mean that many sample companies highly adopted is budgetary control. This type of SMA technique is highly related with traditional management accounting technique. As stated by previous study, the result also found that the highest adopted management accounting practices are related to traditional management accounting practices such as budgeting for controlling cost18. Besides that, second highest SMA technique adopted by manufacturing companies in Malaysia is product profitability analysis. This result also supported the study done by Yap et al who found that product profitability analysis is the highest SMA ranking 
adopted by the manufacturing companies. Next, is followed by standard costing, cost volume profit analysis and target costing (Yap, Lee, Said \& Yap, 2013). This result also revealed that in Malaysia manufacturing companies, budgetary techniques always have the highest ranking. This is similar with Singapore and Indian where budgetary technique was highly adopted in the management accounting (Yap, Lee, Said \& Yap, 2013). Therefore, this results shows that the adoption of SMA in Malaysia manufacturing companies has a good progress if compared to previous study who stated that adoption of SMA is limited (Yap, Lee, Said \& Yap, 2013). So, this study has given an interesting finding about the adoption of SMA in Malaysia manufacturing companies thus supported the results by Noordin et al who found that adoption of SMA in Malaysia has increased in year 2014 (Noordin, Zainuddin, Fuad, \& Mail, 2014).

The second objective is to examine the level if organizational effectiveness as a result of SMA. The respondents were asked to rate either they agree or not strategic management accounting has helped their organization. Table 2 shows the mean results for the organizational effectiveness where it was determined by how the SMA has helped the companies in planning future strategies, controlling current activities, measuring performance, evaluating performance and optimizing use of firm resources.

Table 2: Effectiveness of SMA

\begin{tabular}{|l|l|}
\hline Effectiveness & Mean \\
\hline Planning future strategies & 4.3369 \\
\hline Controlling current activities & 4.2086 \\
\hline Measuring performance & 4.2032 \\
\hline Evaluating performance & 4.1872 \\
\hline Optimizing use of firm resources & 4.1578 \\
\hline
\end{tabular}

Based on the results, it was clearly indicated that all the respondents agreed that SMA has helped their organization for a better performance. This is supported by Yap et al., who stated that there were SMA technique that fall under budgetary group give high benefits to the companies as compared to other technique (Yap, Lee, Said \& Yap, 2013). As we can see from the results in Table 1 and Table 2, most of the respondents who frequently applied budgetary control, product profitability analysis, standard costing cost volume profit analysis agreed that those techniques help to increase organizational effectiveness by planning future strategies, controlling current activities, measuring performance, evaluating performance and optimizing use of firm resources. The most important is SMA will help the companies to plan for better future strategies. It was also supported by previous study who stated that SMA techniques has been adopted to increase the future planning especially the companies' strategic approach and to manage their market competition (Noordin, Zainuddin, Fuad, \& Mail, 2014). 


\section{CONCLUSION}

As being discussed before, strategic management accounting is one of various techniques in accounting that can be apply to simplify strategic management and accounting in an organization thus increase its effectiveness. This paper was done to determine the type of SMA technique adopted by manufacturing companies in Malaysia and to examine the impact of implementation of SMA techniques on organizational effectiveness. Most of the respondents had agreed that they adopted at least one SMA technique in their organizations for better future strategies. Most of the companies had annual sales turnover more than RM25million, thus this shows that multinational companies have widely adopted SMA in their accounting management. Besides, this study also found that SMA techniques have impact on organizational effectiveness especially planning future strategies.

There were some limitations for this study. First, this study only focused on manufacturing companies in Malaysia. Next, this study only aimed at determines the popular SMA technique applied by the companies in Malaysia. Therefore, future research could be done by including other industries in Malaysia with more samples and future research should be done to find the challenges faces by the companies who already adopted SMA in their strategic planning. Besides that, to get the information needed, this study has employed survey questionnaire where in future research, multiple way of data gathering such as interviews and expert's views should be done to avoid personal bias. It is hope that this research will help and give views to other researchers, professionals and academician about SMA and organizational effectiveness in Malaysian context.

\section{Corresponding Author}

Hezlina binti Mohd Hashim, Managament \& Humanities Department, Universiti Teknologi

PETRONAS, 32610 Seri Iskandar, Perak, Malaysia.

Email: hezlina_hashim@utp.edu.my

\section{References}

Abu, M.H., Ali, M. J., \& Khairul, M. Y. (2001). Management Accounting. Journal of Accounting, 42(1), 234-245.

Ashraf, G. \& Abd Kadir, S. (2012). A Review on the Models of Organizational Effectiveness: A Look at Cameron's Model in Higher Education. International Education Studies, 5(2), 80-87. doi:10.5539/ies.v5n2p80

Bromwich, M. (1990). The case for strategic management accounting: th

Hashim, H. binti M., Embong, A. M. bin, \& Sharif, M. A. bin M. (2018). The Impact of Strategic

Management Accounting Adoption on Organizational Effectiveness in Malaysian

Manufacturing Companies. International Journal of Academic Research in Business and Social Sciences, 8(11), 1839-1847.

role of accounting information for strategy in competitive markets. Accounting, Organizations and Society, 15(1), 27-46.

Dixon, R. and Smith, D. (1993), "Strategic management accounting", Omega, 21 (6) 605-18 
INTERNATIONAL JOURNAL OF ACADEMIC RESEARCH IN BUSINESS AND SOCIAL SCIENCES

Vol. 8, No. 11, Nov, 2018, E-ISSN: 2222-6990 @ 2018 HRMARS

Lord, B. (1996), "Strategic management accounting: the emperor's new clothes?" Management Accounting Research, 7 (3) 347-66

Edwinah, A. and Augustine, A. (2013). Employees Involvement and Organizational Effectiveness. Journal of Management Development, 32 (7), 661-674

Indira And Joshi A (2014) A Study Of Factors Affecting Organizational Effectiveness By Fitting The Regression Equation. Pezzottaite Journals, 3(2) 2279-0950

Khan MT, Khan NA, Ahmed S and Ali M (2012) Connotation of Organizational Effectiveness and Factors Affecting It. International Journal of Business and Behavioral Sciences, 2 (9)

Langfield-Smith K. (2008) Strategic management accounting: how far have we come in 25 years? Accounting, Auditing \& Accountability Journal, 21( 2) 204-228

Manzoor Q, (2012). Impact of Employees Motivation on Organizational Effectiveness. Business Management and Strategy. 3 (1)

Noordin, R., Zainuddin, Y., Fuad, \& Mail, R. (2014). Strategic Management Accounting: State-of-theArt. Malaysian Journal of Business and Economics, 1(1), 47-71.

Noordin, R., Zainuddin, Y., \& Tayles, M. (2009). Strategic Management Accounting Information Elements: Malaysian Evidence. Asia-Pasific Management Accounting Journal, 4(1), 17-34.

Roslender R and Hart S.J (2010) Strategic Management Accounting: Lots in a Name? Retrieved from http://www.hw.ac.uk/schools/management-languages/documents/dp2010aef05.pdf

Simon C, and Chris G. (2008). An exploratory investigation of an integrated contingency model of strategic management accounting. Accounting Organization and Society. 33, 836-863

Simmonds, K. (1986). The accounting assessment of competitive position. European Journal of Marketing, 20, 16-32.

Tran Q. and Tian Y. (2013) Organizational Structure: Influencing Factors and Impact on a Firm. American Journal of Industrial and Business Management, 2013 (3) 229-236

Uyar, A. (2010). Cost and Management Accounting Practices: A Survey of manufacturing companies. Eurasian Journal of Business and Economics, 3(6), 113-125.

Vinitwatanakhun, M. W. (1998). Factors affecting organizational effectiveness of nursing institutes in Thailand.1-5. [Online]

Retrieved from : http://www.journal.au.edu/au techno/2002/apr2002/article8.pdf

Hashim, H. binti M., Embong, A. M. bin, \& Sharif, M. A. bin M. (2018). The Impact of Strategic Management Accounting Adoption on Organizational Effectiveness in Malaysian Manufacturing Companies. International Journal of Academic Research in Business and Social Sciences, 8(11), 1839-1847. 